\title{
PERBEDAAN METODE STAD DAN TPS DALAM MENINGKATKAN KERJA SAMA DAN AKTIVITAS BELAJAR PADA PEMBELAJARAN IPS SMP
}

\author{
Novika Malinda Safitri, Taat Wulandari \\ Program Pascasarjana, Universitas Negeri Yogyakarya \\ novikamalindasafitri@yahoo.co.id, taat_wulandari@uny.ac.id
}

\begin{abstract}
Abstrak
Penelitian ini bertujuan untuk mengetahui: (1) perbedaan peningkatan kerja sama siswa antara kelas yang menggunakan metode STAD dan metode TPS dalam pembelajaran IPS di kelas VII SMP Negeri 1 Margoyoso Pati Jawa Tengah, dan (2) perbedaan peningkatan aktivitas belajar siswa antara kelas yang menggunakan metode STAD dan metode TPS dalam pembelajaran IPS di kelas VII SMP Negeri 1 Margoyoso Pati Jawa Tengah. Populasi penelitian ini adalah seluruh siswa kelas VII SMP N 1 Margoyoso Pati Jawa Tengah. Pengambilan sampel dilakukan dengan teknik cluster random sampling dan terpilih kelas VII D diberi perlakuan dengan menggunakan metode STAD dan kelas VII A menggunakan metode TPS. Instrumen yang digunakan adalah instrumen nontes yaitu angket kerja sama dan aktivitas belajar siswa. Validitas instrumen menggunakan analisis faktor. Reliabilitas instrumen diuji dengan rumus Cronbach's Alpha. Uji normalitas data menggunakan Kolmogorov Smirnov dan uji homogenitas menggunakan Levene Test. Pengujian perbedaan peningkatan kerja sama dan aktivitas belajar siswa dianalisis dengan Independent Sample T Test pada taraf signifikansi 0,05. Hasil penelitian menunjukkan bahwa: (1) terdapat perbedaan peningkatan kerja sama siswa yang signifikan antara kelas yang menggunakan metode STAD dan metode TPS dalam pembelajaran IPS di kelas VII SMP Negeri 1 Margoyoso Pati Jawa Tengah, dan (2) terdapat perbedaan peningkatan aktivitas belajar siswa yang signifikan antara kelas yang menggunakan metode STAD dan metode TPS dalam pembelajaran IPS di kelas VII SMP Negeri 1 Margoyoso Pati Jawa Tengah.
\end{abstract}

Kata kunci: student team achievement divison, think pair share, kerja sama siswa, aktivitas belajar siswa

\section{THE DIFFERENCES BETWEEN STAD METHOD AND TPS TO PROMOTE STUDENT'S TEAMWORK AND LEARNING ACTIVITIES ON SOCIAL STUDIES LEARNING IN SMP}

\author{
Novika Malinda Safitri, Taat Wulandari \\ Program Pascasarjana, Universitas Negeri Yogyakarya \\ novikamalindasafitri@yahoo.co.id, taat_wulandari@uny.ac.id
}

\begin{abstract}
This research aims to know: (1) the difference between student's teamwork enhancement using STAD method and TPS method on social studies in class VII SMP N 1 Margoyoso Pati Central Java, and (2) the difference between student's learning activities enhancement using STAD method and TPS method on social studies in class VII SMP N 1 Margoyoso Pati Central Java. The population in this study were all seventh-grade students of SMP N 1 Margoyoso Pati Central Java. Sampling was done by cluster random sampling technique on the group of population which is class VII treated by STAD method and class VII A by TPS method. The instrument used was a non-test instrument which is teamwork instrument and learning activities instrument. The validity of the instrument was measured by factor analysis. The reliability of instrument was measured using Cronbach's Alpha. Data normality test used Kolmogorov Smirnov and homogeneity test used Levene Test. The difference of increased teamwork and learning activities was analyzed by Independent Sample T-Test with the significance level of 0.05. The results show that: (1) there is a significant difference between student's teamwork increase using STAD method and TPS method during social studies learning on the seventh-grade students of SMP N 1 Margoyoso Pati Central Java, and (2) there is a significant difference between the increase of student's learning activities using STAD method and TPS method during social studies learning on the seventh-grade students of SMP N 1 Margoyoso Pati Central Java.
\end{abstract}

Keywords: student team achievement division, think pair share, student's teamwork, student's learning activities 


\section{Pendahuluan}

Pembelajaran merupakan hubungan timbal balik antara guru dengan siswa dan sumber belajar. Guru sebagai ujung tombak dalam pelaksanaan pendidikan merupakan pihak yang sangat berpengaruh dalam proses pembelajaran. Keterampilan guru saat mengajar sangat menentukan kelangsungan pembelajaran di kelas. Guru yang memegang peran penting dalam pembelajaran harus mampu menciptakan kegiatan belajar mengajar secara interaktif, inspiratif, menyenangkan, menantang, dan memotivasi siswa. Hal ini dilakukan untuk menciptakan pembelajaran yang efektif yaitu tujuan pembelajaran dapat tercapai, dengan demikian peran guru dalam pembelajaran harus ditingkatkan dengan sebaikbaiknya. Sesuai dengan Peraturan Peme-rintah No. 32 Tahun 2013 mengenai standar proses pendidikan bahwa (Republik Indonesia, 2013):

"Proses pembelajaran pada satuan pendidikan diselenggarakan secara interaktif, inspiratif, menyenangkan, menantang, memotivasi peserta didik untuk berpartisipasi aktif, serta memberikan ruang yang cukup bagi prakarsa, kreativitas, dan kemandirian sesuai dengan bakat, minat, dan perkembagan fisik serta psikologis peserta didik".

Berdasarkan peraturan pemerintah tersebut dapat dijelaskan bahwa pembelajaran harus dapat diselenggarakan secara interaktif yaitu guru harus menciptakan pembelajaran yang dapat menumbuhkan interaksi antara guru dengan siswa, siswa dengan siswa, dan siswa terhadap sumber belajar. Pembelajaran inspiratif yaitu guru harus merangsang siswa untuk mencoba dan melakukan sesuatu sesuai dengan inspirasinya sendiri. Pembelajaran yang menyenangkan dan menantang yaitu pembelajaran yang dapat menarik perhatian siswa dan menjadikan siswa tertantang untuk lebih mendalami materi pelajaran, sehingga jika pembelajaran dilakukan dengan cara yang interaktif, inspiratif, menyenangkan, dan menantang siswa akan lebih bersemangat dan termotivasi untuk berpartisipasi aktif dalam pembelajaran di kelas.

Pembelajaran yang terjadi selama ini pada kenyataannya masih didominasi guru. Seperti yang diungkapkan Solihatin \& Raharjo (2012, p. 3) situasi pembelajaran di lapangan menunjukkan bahwa: (a) model pembelajaran cenderung konvensional, (b) siswa hanya dijadikan objek pembelajaran, (c) pembelajaran yang berlangsung cenderung didominasi guru, dan (d) dalam pembelajaran pola interaksinya searah yaitu dari guru ke siswa. Selain itu Sutanto (2015, p. 6)mengungkapkan bahwa pengamatan di lapangan banyak ditemui pelaksanaan pembelajaran yang masih kurang variatif, proses pembelajaran memiliki kecenderungan pada metode tertentu (konvensional), tidak memperhatikan tingkat pemahaman siswa terhadap informasi yang disampaikan, dan siswa kurang aktif dalam proses belajar. Hal ini lah yang menyebabkan pembelajaran sulit diselenggarakan secara interaktif, inspiratif, menyenangkan dan menantang sesuai dengan peraturan pemerintah.

Pembelajaran yang interaktif, inspiratif, menyenangkan, dan menantang sangat dibutuhkan di dalam kelas termasuk pembelajaran Ilmu Pengetahuan Sosial (IPS) karena IPS merupakan mata pelajaran yang memiliki cakupan materi sangat luas. Materi IPS terdiri dari berbagai dislipin ilmu sosial seperti: ekonomi, geografi, sejarah, dan sosiologi. Pembelajaran IPS yang terdiri dari berbagai disiplin ilmu tersebut menuntut guru agar dapat menyampaikan materi IPS kepada siswa dengan keterbatasan waktu yang tersedia. Oleh karena itu guru harus kreatif dalam menciptakan strategi pembelajaran agar materi yang disampaikan mudah diterima dan dimengerti dengan baik oleh siswa.

Pembelajaran IPS pada kenyataannya merupakan pelajaran yang sering dianggap hafalan. Seperti yang diungkapkan Supardi (2011, p. 179) bahwa terjadi kesalahan persepsi terhadap IPS tentang anggapan pelajaran ilmu sosial itu pelajaran hafalan dan nomor dua sehingga menjadi penyebab ilmu sosial di sekolah kurang bermakna. Selain itu rendahnya motivasi guru untuk melakukan perubahan dan permbaharuan dalam pengajaran, guru cenderung monoton melakukan yang biasanya dilakukan. Implikasinya bahwa IPS menjadi mata pelajaran yang kurang diminati atau disukai karena terkesan sebagai mata pelajaran hafalan.

Tujuan pembelajaran IPS salah satunya mempersiapkan siswa agar terampil dalam memecahkan masalah-masalah sosial. Menurut Sapriya (2011, p. 12) tujuan IPS adalah mempersiapkan para peserta didik untuk 
menjadi warga negara yang dapat menguasai pengetahuan (knowledge), keterampilan (skill), sikap dan nilai (attitudes and value) yang dapat digunakan sebagai kemampuan dalam memecahkan masalah pribadi maupun masalah sosial. Sehubungan dengan hal tersebut tujuan IPS bukanlah hanya fokus pada penguasaan materi saja, namun harus diimbangi dengan keterampilan, sikap, dan nilai dari dalam diri siswa seperti kerja sama. Kerja sama merupakan hal penting karena manusia adalah makhluk sosial yang membutuhkan interaksi dengan orang lain, sehingga ketika dihadapkan pada masalah-masalah sosial yang ada di masyarakat siswa dapat menyelesaikan secara individu maupun kerja sama dengan orang lain untuk memecahkan masalah tersebut. Hal yang dapat dilakukan dalam membentuk kerja sama siswa yaitu melalui pembelajaran di kelas.

Kerja sama antara guru dengan siswa dan siswa dengan siswa lain dalam pembelajaran sangat dibutuhkan dalam mencapai tujuan pembelajaran karena kerja sama siswa dapat meningkatkan hubungan antarsiswa untuk saling membantu dan memahami materi yang telah diajarkan guru. Kerja sama akan mendorong siswa mendapatkan pengalaman lebih dan meningkatkan sikap positif bagi siswa. Menurut Harsanto (2007, p. 44) manfaat kerja sama siswa yaitu: (1) menanamkan pemahaman saling membantu; (2) membentuk keakraban dan kekompakan; (3) belajar bursama akan meningkatkan kemampuan berkomunikasi dan menyelesaikan konflik; (4) menumbuhkan sikap positif dan kemampuan akademis; (5) mengurangi aspek negatif kompetisi. Kerja sama siswa juga dapat mengurangi fenomena belajar kompetitif dan individualis. Pembelajaran yang individualis mengakibatkan siswa terbiasa nyaman dengan belajar sendiri, tidak peduli dengan teman atau lingkungannya, sehingga hal ini dapat mengakibatkan siswa tidak terlatih secara sosial.

Selain kerja sama, aktivitas belajar siswa merupakan hal penting dalam pembelajaran. Pembelajaran tidak akan berjalan dengan baik tanpa adanya aktivitas karena aktivitas merupakan prinsip yang sangat penting di dalam interaksi belajar mengajar dan tanpa aktivitas proses belajar tidak mungkin berlangsung dengan baik Sardiman (2010, p. 96). Berdasarkan hal tersebut aktivitas siswa sangatlah penting dalam pembelajaran. Aktivitas siswa dalam pembelajaran akan membuat siswa lebih menyerap dan mengingat pengetahuan yang didapatkan secara langsung. Siswa tidak hanya menerima penjelasan dari guru saja, namun siswa akan menemukan dan menyerap sendiri pengetahuan yang didapatkan pada saat pembelajaran. Jika siswa aktif dalam pembelajaran, maka potensi yang ada dalam diri siswa akan berkembang.

Pentingnya kerja sama dan aktivitas belajar siswa perlu dikembangkan agar tujuan pembelajaran dapat tercapai secara optimal. Pembelajaran yang optimal dapat dicapai salah satunya melalui penggunaan metode pembelajaran yang bervariatif. Pada zaman sekarang ini banyak metode-metode pembelajaran yang dirancang untuk dapat digunakan di dalam kelas. Guru sebagai pendidik tentunya memiliki hak otoritas untuk memilih metode yang tepat digunakan dalam mengajar. Metode yang dapat mendorong kerja sama dan aktivitas belajar siswa dalam pembelajaran adalah metode pembelajaran kooperatif.

Metode pembelajaran kooperatif merupakan metode pembelajaran yang melibatkan siswa ke dalam beberapa kelompok kecil untuk saling berinteraksi dan bekerja sama membahas dan menyelesaikan tugas-tugas guna mencapai tujuan bersama. Dalam kelompok-kelompok kecil siswa akan lebih banyak terlibat, saling membantu antarsiswa, saling mengemukakan pendapat, dan bertanggung jawab belajar untuk dirinya sendiri maupun anggota kelompok. Pembelajaran kooperatif menurut Huda (2011, p. 32) merupakan pembelajaran yang mengondisikan siswa untuk bekerja sama dalam kelompok kecil yang heterogen dan saling membantu dalam belajar. Melalui metode pembelajaran kooperatif diharapkan di kelas siswa dapat aktif secara individu, aktif berdiskusi, berani bertanya, berani mengemukakan pendapat, dan menerima gagasan dari orang lain.

Metode pembelajaran kooperatif memiliki banyak tipe seperti metode STAD, TPS, TGT, Jigsaw, NHT, dan sebagainya. Metode yang dapat mendorong kerja sama dan aktivitas belajar siswa yaitu metode Student Team Achievement Division (STAD) dan metode Think Pair Share (TPS). Hal ini dikarenakan metode STAD merupakan metode yang paling sederhana untuk digunakan sebagai awal permulaan menerapkan pembelajaran kooperatif. Metode pembelajaran ini akan mendorong siswa dapat bekerja sama 
dan bertanggung jawab terhadap tugas mereka. Sehingga guru berfungsi sebagai fasilitator yang mengatur dan mengawasi jalannya proses belajar (Zubaedi, 2011, p. 221). Metode STAD mendorong siswa memiliki tanggung jawab kelompok untuk pembelajaran individu atau anggotanya. Tiap anggota bekerja sama dalam menyelesaikan suatu masalah yang diberikan guru. Dalam metode STAD para siswa diharapkan dapat saling membantu, saling mendikusikan dan berpendapat sehingga pembelajaran kooperatif STAD dapat mendorong kerja sama dan aktivitas belajar siswa.

Metode TPS memberikan siswa waktu lebih banyak untuk berpikir secara individual, menjawab, dan membantu sama lain. Pembelajaran ini sangat memungkinkan bila siswa dapat berdiskusi dan saling bertukar pikiran, sehingga dalam metode ini siswa dituntut untuk dapat bekerja sama dengan temannya agar mencapai tujuan bersama dan mendorong aktivitas siswa dalam pembelajaran. Dalam metode ini guru hanya berperan sebagi fasilitator dan menyajikan suatu materi dalam waktu pembahasan yang relatif singkat. Setelah itu giliran siswa untuk memikirkan secara mendalam tentang apa yang telah dijelaskan. Lie (2004, p. 57) menjelaskan bahwa siswa secara individu dapat mengembangkan pemikirannya masing-masing karena adanya waktu berpikir (think time), sehingga kualitas jawaban juga dapat meningkat, dan akuntabilitas berkembang karena siswa harus saling melaporkan hasil pemikiran masing-masing dan berbagi (berdiskusi) dengan pasangannya, kemudian pasangan-pasangan tersebut harus berbagi dengan teman atau seluruh kelas. Jumlah anggota kelompok yang kecil mendorong setiap anggota untuk terlibat aktif, sehingga siswa jarang atau bahkan tidak pernah berbicara di depan kelas paling tidak memberikan ide atau jawaban karena pasangannya.

Metode STAD dan metode TPS termasuk dalam pembelajaran kooperatif yang menekankan pada kerjasama dan aktivitas antaranggota kelompoknya. Namun kerja sama dan aktivitas belajar siswa juga tidak terlepas dari bagaimana pembelajaran siswa di dalam kelas tersebut. Oleh karena itu peneliti tertarik untuk mengkaji perbedaan metode STAD dan TPS dalam meningkatkan kerja sama dan aktivitas belajar siswa pada pembelajaran IPS di kelas VII SMP Negeri 1 Margoyoso Pati Jawa Tengah.
Variabel bebas dalam penelitian ini adalah metode Student Team Achievement Division $\left(\mathrm{X}_{1}\right)$ dan metode Think Pair Share $\left(\mathrm{X}_{2}\right)$ sedangkan variabel terikat dalam penelitian ini adalah kerjasama siswa $\left(\mathrm{Y}_{1}\right)$ dan aktivitas belajar siswa $\left(\mathrm{Y}_{2}\right)$.

Kerjasama siswa dalam pembelajaran dapat diartikan sebagai hubungan timbal balik antara siswa dengan guru dan siswa dengan siswa untuk mencapai tujuan pembelajaran. Indikator kerjasama siswa antara lain: (1) saling membantu sesama anggota dalam kelompok; (2) setiap anggota ikut serta dalam memecahkan masalah kelompok sehingga mencapai kesepakatan bersama; (3) menghargai pendapat setiap anggota kelompok; (4) setiap anggota kelompok dapat mengambil giliran dan berbagi tugas; (5) berada dalam kelompok selama kegiatan berlangsung; (6) mengemban tugas yang telah menjadi tanggung jawabnya; (7) mendorong partisipasi siswa lain untuk berkontribusi dalam tugas kelompok; (8) menyelesaikan tugas tepat waktu. Kerja sama dalam penelitian ini akan diukur dengan menggunakan angket yang diberikan kepada siswa.

Aktivitas belajar siswa adalah segala kegiatan yang dilakukan di kelas yang meliputi aktivitas fisik dan aktivitas mental. Indikator aktivitas siswa yaitu: (1) visual activities yaitu memperhatikan penjelasan guru dan siswa lain, membaca materi yang sedang dipelajari; (2) oral activities yaitu bertanya kepada guru atau siswa, menjawab pertanyaan dari guru maupun siswa lain, mengemukakan pendapat; (3) listening activities yaitu mendengarkan penjelasan guru dan siswa lain; (4) writing activities yaitu mencatat materi yang disampaikan menulis pertanyaan dan jawaban; (5) motor activities yaitu maju di depan kelas untuk presentasi, mengangkat tangan saat ingin bertanya dan menjawab; (6) mental activities yaitu mengingat kembali materi, memecahkan masalah, memberi kesimpulan; (7) emotional activities yaitu bersemangat. Dalam penelitian ini peneliti menggunakan angket untuk mengukur aktivitas siswa.

Metode pembelajaran Student Team Achievement Division merupakan metode yang paling sederhana untuk permulaan menggunakan metode kooperatif. Metode STAD juga dapat melatih siswa untuk bekerja sama dengan siswa lain dalam mengerjakan tugas kelompok yang diberikan oleh guru. Langkahlangkah pembelajaran menggunakan metode 
pembelajaran STAD sebagai berikut: (1) guru menyampaikan materi pelajaran kepada siswa; (2) guru memberikan tes/kuis kepada siswa secara individual untuk diperoleh skor awal siswa; (3) siswa dibagi menjadi beberapa kelompok kecil yang setiap kelompok terdiri dari dari 4-5 siswa yang heterogen; (4) guru memberikan lembar kerja kelompok untuk didiskusikan kepada masing-masing kelompok; (5) masing-masing kelompok menyampaikan hasil diskusi kelompok di depan kelas; (6) guru mengevaluasi dengan memberikan kuis atau tes, dan melakukan penilaian terhadap hasil kerja kelompok; (7) guru memberikan penghargaan kepada kelompok yang memperoleh nilai tertinggi.

Metode Think Pair Share merupakan metode pembelajaran yang memberikan kesempatan kepada siswa untuk berpikir, merespon, dan saling membantu antara siswa dengan siswa lainnya untuk memecahkan masalah secara bersama-sama. Metode ini memiliki 3 tahapan yaitu berpikir, berpasangan dan berbagi. Langkah-langkah metode pembelajaran TPS antara lain: (1) guru menyampaikan materi pelajaran kepada siswa; (2) guru memberikan suatu permasalahan/pertanyaan dan setiap siswa secara individual diminta untuk memikirkan jawabannya; (3) setelah siswa mencari/memikirkan jawaban secara individu, guru kemudian meminta siswa secara berpasangan mendiskusikan jawaban mereka; (4) setelah diskusi berpasangan, tiap siswa/pasangan siswa diminta untuk berbagi jawaban atau komentar di depan kelas terhadap permasalahan yang diajukan guru.

Berdasarkan uraian tersebut, maka penelitian ini bertujuan untuk mengetahui: (1) perbedaan peningkatan kerja sama siswa antara kelas yang menggunakan metode STAD dan metode TPS dalam pembelajaran IPS di kelas VII SMP Negeri 1 Margoyoso Pati Jawa Tengah, dan (2) perbedaan peningkatan aktivitas belajar siswa antara kelas yang menggunakan metode STAD dan metode TPS dalam pembelajaran IPS di kelas VII SMP Negeri 1 Margoyoso Pati Jawa Tengah.

\section{Metode}

Jenis penelitian ini merupakan penelitian quasi exsperiment (eksperimen semu) yang dimaksudkan untuk mengetahui akibat dari suatu perlakuan. Penelitian ini dikatakan eksperimen semu karena peneliti tidak mengontrol semua variabel-variabel luar yang mempengaruhi pelaksanaan eksperimen.

Desain penelitian yang digunakan dalam penelitian ini adalah pretest-posttest nonequivalent group design (Arifin, 2011, p. 88). Desain eksperimen kuasi dalam penelitian ini disajikan pada Tabel 1.

Tabel 1. Desain Penelitian

\begin{tabular}{llll}
\hline Kelompok & Pretest & Perlakuan & Posttest \\
\hline KE 1 & $0_{1}$ & $\mathrm{X}_{1}$ & $0_{2}$ \\
KE 2 & $0_{3}$ & $\mathrm{X}_{2}$ & $0_{4}$ \\
\hline
\end{tabular}

Keterangan:

$\mathrm{KE}=$ Kelas eksperimen

$0_{1} \quad=$ Pretest Kelas Eksperimen 1

$\mathrm{O}_{2} \quad=$ Posttest Kelas Eksperimen 1

$0_{3} \quad=$ Pretest Kelas Eksperimen 2

$0_{4} \quad=$ Posttest Kelas Eksperimen 2

$\mathrm{X}_{1}=$ Metode STAD

$\mathrm{X}_{2}=$ Metode TPS

Berdasarkan desain penelitian di atas dapat dijelaskan bahwa dalam penelitian ini melibatkan 2 kelompok dalam pembelajaran IPS yaitu kelompok eksprimen 1 kelas VII D dan kelompok eksperimen 2 kelas VII A. Kedua kelas tersebut diberi perlakuan dalam pembelajaran IPS menggunakan metode STAD untuk kelas D dan metode TPS untuk kelas VII A. Tahap-tahap penelitian ini sebagai berikut: (a) melakukan prasurvei dan mengajukan perijinan ke sekolah; (b) pembuatan instrumen dan uji validitas instrumen; (c) mengadakan pertemuan koordinasi guru dan diskusi mengenai metode STAD dan metode TPS; (d) mengembangkan pendekatan pembelajaran bersama-sama dengan guru pada kelompok eksperimen satu dan kelompok eksperimen dua; (e) melaksanakan pretest yang kemudian dilanjutkan dengan eksperimen; (f) melaksanakan posttest setelah eksperimen; dan $(\mathrm{g})$ analisis data.

Penelitian ini dilakukan di SMP Negeri 1 Margoyoso yang beralamat di Jalan Kiai Cebolang 17 Margoyoso Pati Jawa Tengah. Penelitian ini dilaksanakan pada bulan september 2015 sampai mei 2016. Pengambilan data dilakukan pada bulan Januari sampai Maret 2016. Populasi dalam penelitian ini adalah seluruh kelas VII SMP Negeri 1 Margoyoso Tahun Ajaran 2015/2016 sebanyak 256 siswa. Pengambilan sampel dilakukan 
dengan teknik cluster random sampling pada kelas VII yaitu dengan cara mengundi untuk mencari 2 kelas dari 8 kelas yang ada secara acak. Dalam pengambilan sampel tersebut peneliti mencampur nama-nama kelompok/ kelas di dalam populasi, sehingga semua kelompok dianggap sama dengan demikian peneliti memberi hak yang sama untuk memperoleh kesempatan dipilih menjadi sampel. Cara undiannya yaitu menggunakan gulungan kertas. Berdasarkan hasil cluster random sampling yang dilakukan terpilih dua kelas, yaitu kelas VII D dengan menggunakan metode STAD dan kelas eksperimen dua kelas VII A menggunakan metode TPS

Teknik pengumpulan data yang digunakan dalam penelitian ini adalah non-tes. Teknik non-tes berupa angket kerja sama dan aktivitas belajar siswa dalam pembelajaran IPS dengan menggunakan metode Student Team Achievement Division dan metode Think Pair Share. Angket dalam penelitian ini ditujukan kepada siswa. Siswa mengisi angket dengan memberikan tanda $\sqrt{ }$ sesuai kondisi yang dialaminya pada setiap pernyataan.

Instrumen dalam penelitian ini adalah Instrumen angket kerja sama siswa dan aktivitas belajar siswa. Instruemen angket kerja sama dan aktivitas belajar siswa diberikan kepada siswa dalam pembelajaran IPS menggunakan metode STAD dan metode TPS. Data angket kerja sama aktivitas belajar siswa dinilai menggunakan penilaian diri dalam bentuk check list dengan skala penilaian 1-4. Siswa memilih salah satu jawaban dari 4 kategori yang disediakan yaitu SL (Selalu), 3 untuk SR (Sering), 2 untuk KD (Kadangkadang), 1 untuk TP (Tidak Pernah).

Data hasil angket kerja sama dan aktivitas belajar siswa digunakan untuk mengetahui ada tidaknya perbedaan antara hasil angket pretest dan posttest. Hasil pretest dan posttest angket kerja sama dan aktivitas belajar siswa digunakan untuk mengetahui gainscore atau kenaikan yang terjadi antara sebelum dan sesudah diberi perlakuan menggunakan metode STAD dan TPS. Nilai gainscore dapat menunjukkan bahwa nilai yang bagus tidak semata-mata karena input siswa, namun pengaruh metode yang diberikan selama pembelajaran. Pada tiap kelompok dianalisis melalui tiga tahapan yaitu, tahap deskripsi data, tahap uji prasyarat analisis, dan tahap pengujian hipotesis.
Langkah-langkah yang dilakukan pada tahap deskripsi data adalah tabulasi data untuk setiap variabel, mengurutkan data secara interval dan menyusunnya dalam bentuk tabel distribusi frekuensi, mencari modus, median, rata-rata (mean), dan simpangan baku.

Sebelum melakukan uji hipotesis, dilakukan uji prasyarat analisis yaitu uji normalitas dan uji homogenitas. Pengujian normalitas dalam penelitian ini menggunakan uji Kolmogorov-Smirnov. Uji ini digunakan untuk mengetahui apakah sampel yang digunakan untuk penelitian ini berasal dari populasi yang berdistribusi normal atau tidak. Uji homogenitas varians menggunakan Levene-Test. Uji ini bertujuan untuk mengetahui dua kelompok mempunyai varians yang sama atau tidak.

Pengujian hipotesis pada penelitian ini menggunakan Independent Sample T Test. Pengambilan keputusan dapat didasarkan pada signifikansi yang diperoleh, yaitu jika signifikansi $<0,05$ maka $\mathrm{H}_{\mathrm{o}}$ ditolak sedangkan jika signifikansi $>0,05$ maka $\mathrm{H}_{\mathrm{o}}$ diterima.

\section{Hasil dan Pembahasan}

Hasil Pretest Angket Kerja Sama dan Aktivitas Belajar Siswa Menggunakan Metode STAD dan TPS.

Tabel 2. Distribusi Frekuensi Skor Kerja sama dan Aktivitas Belajar Siswa Pretest Kelompok STAD dan TPS.

\begin{tabular}{|c|c|c|c|c|c|}
\hline \multirow{3}{*}{ Kategori } & \multirow{3}{*}{$\begin{array}{c}\text { Rentang } \\
\text { skor }\end{array}$} & \multicolumn{4}{|c|}{ Pretest Kerja sama } \\
\hline & & \multicolumn{2}{|c|}{ STAD } & \multicolumn{2}{|c|}{ TPS } \\
\hline & & $\mathrm{F}$ & $\%$ & $\mathrm{~F}$ & $\%$ \\
\hline Sangat baik & $>85$ & 1 & $3,13 \%$ & - & - \\
\hline Baik & $70-85$ & 7 & $21,87 \%$ & 6 & $18,75 \%$ \\
\hline Cukup & $55-79$ & 14 & $43,75 \%$ & 12 & $37,50 \%$ \\
\hline Kurang & $40-55$ & 6 & $18,75 \%$ & 11 & $34,37 \%$ \\
\hline Sangat kurang & $<40$ & 4 & $12,50 \%$ & 3 & $9,38 \%$ \\
\hline Jumlah & & 32 & $100 \%$ & 32 & $100 \%$ \\
\hline \multirow{3}{*}{ Kategori } & \multirow{3}{*}{$\begin{array}{c}\text { Rentang } \\
\text { skor }\end{array}$} & \multicolumn{4}{|c|}{ Pretest Aktivitas } \\
\hline & & \multicolumn{2}{|c|}{ STAD } & \multicolumn{2}{|r|}{ TPS } \\
\hline & & $\mathrm{F}$ & $\%$ & $\mathrm{~F}$ & $\%$ \\
\hline Sangat baik & $>85$ & 2 & $6,25 \%$ & 2 & $6,25 \%$ \\
\hline Baik & $70-85$ & 6 & $18,75 \%$ & 5 & $15,62 \%$ \\
\hline Cukup & $55-79$ & 13 & $40,62 \%$ & 10 & $31,25 \%$ \\
\hline Kurang & $40-55$ & 8 & $25,00 \%$ & 9 & $28,13 \%$ \\
\hline Sangat kurang & $<40$ & 3 & $9,38 \%$ & 6 & $18,75 \%$ \\
\hline Jumlah & & 32 & $100 \%$ & 32 & $100 \%$ \\
\hline
\end{tabular}

Sumber: Olah data 2016 
Berdasarkan Tabel 2 menunjukkan bahwa pretest kerja sama STAD memiliki kategori sangat baik sebanyak 1 siswa dengan persentase $3,13 \%$, kategori baik sebanyak 7 siswa dengan persentase $21,87 \%$, kategori cukup sebanyak 14 siswa dengan persentase $43,75 \%$, kategori kurang sebanyak 6 siswa dengan persentase $18,75 \%$, dan kategori sangat kurang sebanyak 4 siswa dengan persentase $12,50 \%$, sedangkan pretest kerja sama TPS menunjukkan bahwa tidak ada siswa dengan kategori sangat baik, kategori baik sebanyak 6 siswa dengan persentase $18,75 \%$, kategori cukup sebanyak 12 siswa dengan persentase $37,50 \%$, kategori kurang sebanyak 11 siswa dengan persentase $34,37 \%$, dan kategori sangat kurang 3 siswa dengan persentase $9,38 \%$. Pretest aktivitas belajar siswa pada kelompok STAD menunjukkan kategori sangat baik sebanyak 2 siswa dengan persentase $6,25 \%$, kategori baik sebanyak 6 siswa dengan kategori $18,75 \%$, kategori cukup sebanyak 13 siswa dengan persentase $40,62 \%$, kategori kurang sebanyak 8 siswa dengan persentase $25,00 \%$, dan kategori sangat kurang sebanyak 3 siswa dengan persentase $9,38 \%$, sedangkan pretest aktivitas belajar siswa kelompok TPS menunjukkan bahwa kategori sangat baik sebanyak 2 siswa dengan persentase $6,25 \%$, kategori baik sebanyak 5 siswa dengan persentase $15,62 \%$, kategori cukup sebanyak 10 siswa dengan persentase $31,25 \%$, kategori kurang sebanyak 9 dengan persentase $28,13 \%$, dan kategori sangat kurang sebanyak 6 siswa dengan persentase $18,75 \%$. Jadi, dapat disimpulkan bahwa pretest kerja sama dan aktivitas belajar siswa memiliki kategori yang hampir sama antara kelompok STAD dan TPS.

Hasil pretest kerja sama siswa kelompok STAD menunjukkan bahwa rata-ratanya 56,34, median 55,00, standar deviasi 12,04, nilai minimal 38 , nilai maksimal 86 , yang artinya termasuk dalam kategori cukup, sedangkan hasil pretest kerja sama siswa kelompok TPS menunjukkan bahwa rata-ratanya 55,75, median 55,00, standar deviasi 11,75 , nilai minimal 38, dan nilai maksimal 80, termasuk kategori cukup. Hasil pretest aktivitas belajar siswa kelompok STAD menunjukkan bahwa rata-ratanya 58,28, median 55,50, standar deviasi 11,70 , nilai minimal 40 , dan nilai maksimal 85 , yang berarti termasuk dalam kategori cukup, sedangkan hasil pretest aktivitas belajar siswa kelompok TPS menunjukkan bahwa rata-ratanya 57,50, median 55,00, standar deviasi 12,31 nilai minimal 39, dan nilai maksimal 86, termasuk dalam kategori cukup, dapat disimpulkan bahwa pretest kerja sama dan aktivitas belajar siswa kelompok STAD dan TPS termasuk dalam kategori cukup.

Tabel 3. Distribusi Skor Kerja sama dan Aktivitas Belajar Siswa Pretest Kelompok STAD dan TPS.

\begin{tabular}{|c|c|c|c|c|}
\hline & $\begin{array}{c}\text { Pretest } \\
\text { kerja sama } \\
\text { STAD }\end{array}$ & $\begin{array}{c}\text { Pretest } \\
\text { kerja sama } \\
\text { TPS }\end{array}$ & $\begin{array}{c}\text { Pretest } \\
\text { Aktivitas } \\
\text { STAD }\end{array}$ & $\begin{array}{c}\text { Pretest } \\
\text { Aktivitas } \\
\text { TPS }\end{array}$ \\
\hline Mean & 56.34 & 55.75 & 58.28 & 57.50 \\
\hline Median & 55.00 & 55.00 & 55.50 & 55.00 \\
\hline Mode & 55 & 55 & 55 & 54 \\
\hline Std. Deviation & 12.045 & 11.747 & 11.701 & 12.313 \\
\hline Variance & 145.072 & 138.000 & 136.918 & 151.613 \\
\hline Range & 48 & 42 & 45 & 47 \\
\hline Minimum & 38 & 38 & 40 & 39 \\
\hline Maximum & 86 & 80 & 85 & 86 \\
\hline Sum & 1803 & 1784 & 1865 & 1840 \\
\hline
\end{tabular}

Sumber: olah data 2016

Hasil pretest memberikan gambaran awal terkait kemampuan siswa dan memberikan pengertian bahwa kelompok STAD dan TPS memiliki kategori yang sama, sehingga dapat dianggap kemampuan awal kedua kelompok tersebut hampir sama. Kemampuan awal yang hampir sama diharapkan nantinya akan memperoleh hasil penelitian yang lebih valid.

Hasil Posttest Angket Kerja sama dan Aktivitas Belajar Menggunakan Metode STAD dan TPS

Berdasarkan Tabel 4 menunjukkan bahwa posttest kerja sama STAD memiliki kategori sangat baik sebanyak 15 siswa dengan persentase $46,88 \%$, kategori baik sebanyak 12 siswa dengan persentase $37,50 \%$, kategori cukup sebanyak 5 siswa dengan persentase $15,62 \%$, kategori kurang dan sangat kurang tidak ada, sedangkan posttest kerja sama TPS menunjukkan bahwa kategori sangat baik sebanyak 10 siswa dengan persentase $31,25 \%$, kategori baik sebanyak 13 siswa dengan persentase $40,62 \%$, kategori cukup sebanyak 9 siswa dengan persentase $28,13 \%$, kategori kurang dan sangat kurang tidak ada. Posttest aktivitas belajar siswa pada kelompok STAD menunjukkan kategori sangat baik sebanyak 18 siswa dengan persentase $56,25 \%$, kategori 
baik sebanyak 10 siswa dengan persentase $31,25 \%$, kategori cukup sebanyak 4 siswa dengan persentase $12,50 \%$, kateregori kurang dan sangat kurang tidak ada, sedangkan posttest aktivitas belajar siswa kelompok TPS menunjukkan bahwa kategori sangat baik sebanyak 10 siswa dengan persentase $31,25 \%$ kategori baik sebanyak 15 siswa dengan persentase 46,88\%, kategori cukup sebanyak 7 siswa dengan persentase $21,87 \%$, kategori kurang dan sangat kurang tidak ada. Jadi dapat disimpulkan bahwa posttest kerja sama dan aktivitas belajar siswa kelompok STAD dan TPS memiliki kategori yang hampir sama.

Tabel 4. Distribusi Frekuensi Skor Kerja sama dan Aktivitas Belajar Siswa Posttest Kelompok STAD dan TPS

\begin{tabular}{|c|c|c|c|c|c|}
\hline \multirow{3}{*}{ Kategori } & \multirow{3}{*}{$\begin{array}{c}\text { Rentang } \\
\text { skor }\end{array}$} & \multicolumn{4}{|c|}{ Posttest Kerja sama } \\
\hline & & \multicolumn{2}{|c|}{ STAD } & \multicolumn{2}{|c|}{ TPS } \\
\hline & & $\mathrm{F}$ & $\%$ & $\mathrm{~F}$ & $\%$ \\
\hline Sangat Baik & $>85$ & 15 & $46,88 \%$ & 10 & $31,25 \%$ \\
\hline Baik & $70-85$ & 12 & $37,50 \%$ & 13 & $40,62 \%$ \\
\hline Cukup & $55-79$ & 5 & $15,62 \%$ & 9 & $28,13 \%$ \\
\hline Kurang & $40-55$ & - & - & - & - \\
\hline Sangat Kurang & $<40$ & - & - & - & - \\
\hline Jumlah & & 32 & $100 \%$ & 32 & $100 \%$ \\
\hline \multirow{3}{*}{ Kategori } & \multirow{3}{*}{$\begin{array}{l}\text { Rentang } \\
\text { skor }\end{array}$} & \multicolumn{4}{|c|}{ Posttest Aktivitas } \\
\hline & & \multicolumn{2}{|c|}{ STAD } & \multicolumn{2}{|r|}{ TPS } \\
\hline & & $\mathrm{F}$ & $\%$ & $\mathrm{~F}$ & $\%$ \\
\hline Sangat Baik & $>85$ & 18 & $56,25 \%$ & 10 & $31,25 \%$ \\
\hline Baik & $70-85$ & 10 & $31,25 \%$ & 15 & $46,88 \%$ \\
\hline Cukup & $55-79$ & 4 & $12,50 \%$ & 7 & $21,87 \%$ \\
\hline Kurang & $40-55$ & - & - & - & - \\
\hline Sangat Kurang & $<40$ & - & - & - & - \\
\hline Jumlah & & 32 & $100 \%$ & 32 & $100 \%$ \\
\hline
\end{tabular}

Tabel 5. Distribusi Skor Kerja sama Siswa dan Aktivitas Belajar Siswa Posttest Kelompok STAD dan TPS

\begin{tabular}{|c|c|c|c|c|}
\hline & $\begin{array}{c}\text { Posttest } \\
\text { kerja sama } \\
\text { STAD }\end{array}$ & $\begin{array}{c}\text { Posttest } \\
\text { kerja sama } \\
\text { TPS }\end{array}$ & $\begin{array}{l}\text { Posttest } \\
\text { Aktivitas } \\
\text { STAD }\end{array}$ & $\begin{array}{c}\text { Posttest } \\
\text { Aktivitas } \\
\text { TPS }\end{array}$ \\
\hline Mean & 86.03 & 80.44 & 85.16 & 78.34 \\
\hline Median & 84.00 & 82.00 & 87.00 & 75.50 \\
\hline Mode & 96 & 84 & 95 & 70 \\
\hline Std. Deviation & 9.488 & 9.748 & 9.395 & 9.300 \\
\hline Variance & 90.031 & 95.028 & 88.265 & 86.491 \\
\hline Range & 30 & 32 & 29 & 31 \\
\hline Minimum & 66 & 63 & 66 & 64 \\
\hline Maximum & 96 & 95 & 95 & 95 \\
\hline Sum & 2753 & 2574 & 2725 & 2507 \\
\hline
\end{tabular}

Sumber: Olah data 2016
Hasil Posttest kerja sama siswa kelompok STAD menunjukkan bahwa rataratanya 86,03 , median 84,00 , standar deviasi 9,49 , nilai minimal 66 , dan nilai maksimal 96 , yang berarti termasuk dalam kategori sangat baik, sedangkan hasil posttest kerja sama siswa kelompok TPS menunjukkan bahwa rata-ratanya 80,44 median 82,00 dan standar deviasi 9,75 , nilai minimal 63 , dan nilai maksimal 95, termasuk kategori baik. Hasil posttest aktivitas belajar siswa kelompok STAD menunjukkan bahwa rata-ratanya 85,16 , median 87,00, standar deviasi 9,40 nilai minimal 66, dan nilai maksimal 95 yang berarti termasuk dalam kategori sangat baik, sedangkan hasil posttest aktivitas belajar siswa kelompok TPS menunjukkan bahwa rata-rata 78,34, median 75,50, standar deviasi 9,30, nilai minimal 64, dan nilai maksimal 95, termasuk dalam kategori baik, dapat disimpulkan bahwa posttest kerja sama dan aktivitas belajar siswa kelompok STAD memiliki kategori sangat baik sedangkan posttest kerja sama dan aktivitas belajar siswa kelompok TPS memiliki kategori baik.

Hasil Pretest dan Posttest Angket Kerja Sama Siswa Menggunakan Metode STAD dan TPS

Tabel 6. Distribusi Skor Kerja sama Siswa Pretest dan Posttest Kelompok STAD dan TPS

\begin{tabular}{|c|c|c|c|c|}
\hline & $\begin{array}{c}\text { Pretest } \\
\text { kerja sama } \\
\text { STAD }\end{array}$ & $\begin{array}{c}\text { Posttest } \\
\text { kerja sama } \\
\text { STAD }\end{array}$ & $\begin{array}{c}\text { Pretest } \\
\text { kerja sama } \\
\text { TPS }\end{array}$ & $\begin{array}{c}\text { Posttest } \\
\text { kerja sama } \\
\text { TPS }\end{array}$ \\
\hline Mean & 56.34 & 86.03 & 55.75 & 80.44 \\
\hline Median & 55.00 & 84.00 & 55.00 & 82.00 \\
\hline Mode & 55 & 96 & 55 & 84 \\
\hline Std. Deviation & 12.045 & 9.488 & 11.747 & 9.748 \\
\hline Variance & 145.072 & 90.031 & 138.000 & 95.028 \\
\hline Range & 48 & 30 & 42 & 32 \\
\hline Minimum & 38 & 66 & 38 & 63 \\
\hline Maximum & 86 & 96 & 80 & 95 \\
\hline Sum & 1803 & 2753 & 1784 & 2574 \\
\hline Gainscore & 29,69 & & 24,69 & \\
\hline Persentase & $52,70 \%$ & & $44,28 \%$ & \\
\hline
\end{tabular}

Hasil pretest dan posttest angket kerja sama siswa digunakan untuk mengetahui gainscore atau kenaikan yang terjadi antara sebelum dan sesudah diberi perlakuan menggunakan metode STAD dan TPS. Nilai gain- 
score dapat menunjukkan bahwa nilai yang bagus tidak semata-mata karena input siswa, namun pengaruh metode yang diberikan selama pembelajaran. Kenaikan antara pretest dan posttest kerja sama siswa dapat dilihat pada Tabel 6.

Berdasarkan hasil pretest dan posttest kerja sama siswa kelompok STAD menunjukkan bahwa nilai gainscore sebesar 29,69 dengan persentase $52,70 \%$ sedangkan kerja sama siswa kelompok TPS memiliki nilai gainscore sebesar 24,69 dengan persentase $44,28 \%$. Hal ini dapat diartikan bahwa peningkatan kerja sama siswa pada kelompok STAD lebih tinggi dibandingkan dengan kelompok TPS, dapat dibandingkan secara visual pada Gambar 1.

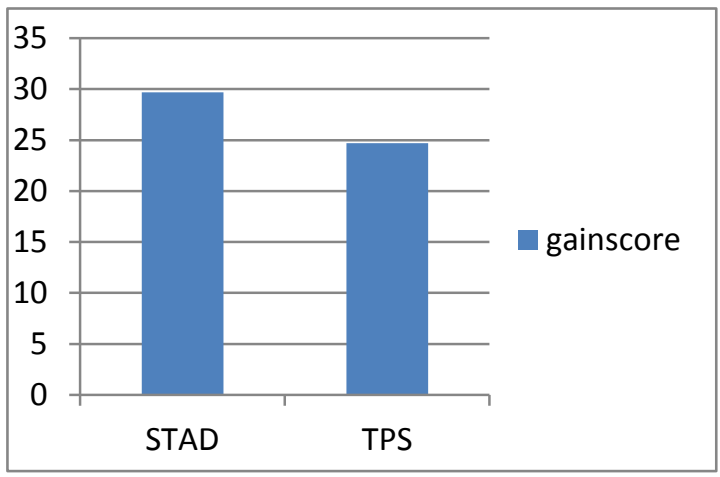

Gambar 1. Perbandingan Gainscore Kerja sama Siswa Kelompok STAD dan TPS

Hasil Pretest dan Posttest Angket Aktivitas Belajar Siswa Menggunakan Metode STAD dan TPS

Tabel 7. Distribusi Skor Aktivitas Belajar Siswa Pretest dan posttest Kelompok STAD dan TPS

\begin{tabular}{|c|c|c|c|c|}
\hline & $\begin{array}{l}\text { Pretest } \\
\text { Aktivitas } \\
\text { STAD }\end{array}$ & $\begin{array}{l}\text { Posttest } \\
\text { Aktivitas } \\
\text { STAD }\end{array}$ & $\begin{array}{l}\text { Pretest } \\
\text { Aktivitas } \\
\text { TPS }\end{array}$ & $\begin{array}{l}\text { Posttest } \\
\text { Aktivitas } \\
\text { TPS }\end{array}$ \\
\hline Mean & 58.28 & 85.16 & 57.50 & 78.34 \\
\hline Median & 55.50 & 87.00 & 55.00 & 75.50 \\
\hline Mode & 55 & 95 & 54 & 70 \\
\hline Std. Deviation & 11.701 & 9.395 & 12.313 & 9.300 \\
\hline Variance & 136.918 & 88.265 & 151.613 & 86.491 \\
\hline Range & 45 & 29 & 47 & 31 \\
\hline Minimum & 40 & 66 & 39 & 64 \\
\hline Maximum & 85 & 95 & 86 & 95 \\
\hline Sum & 1865 & 2725 & 1840 & 2507 \\
\hline Gainscore & 26,88 & & 20,84 & \\
\hline Persentase & $46,12 \%$ & & $36,24 \%$ & \\
\hline
\end{tabular}

Sumber: Olah data 2016
Berdasarkan hasil pretest dan posttest aktivitas belajar siswa kelompok STAD menunjukkan bahwa nilai gainscore sebesar 26,88 dengan persentase $46,12 \%$ sedangkan aktivitas belajat siswa kelompok TPS memiliki nilai gainscore sebesar 20,84 dengan persentase $36,24 \%$. Hal ini dapat diartikan bahwa peningkatan aktivitas belajar siswa pada kelompok STAD lebih tinggi dibandingkan kelompok TPS, dapat dibandingkan secara visual antara gainscore aktivitas belajar siswa pada metode STAD dan TPS pada Gambar 2.

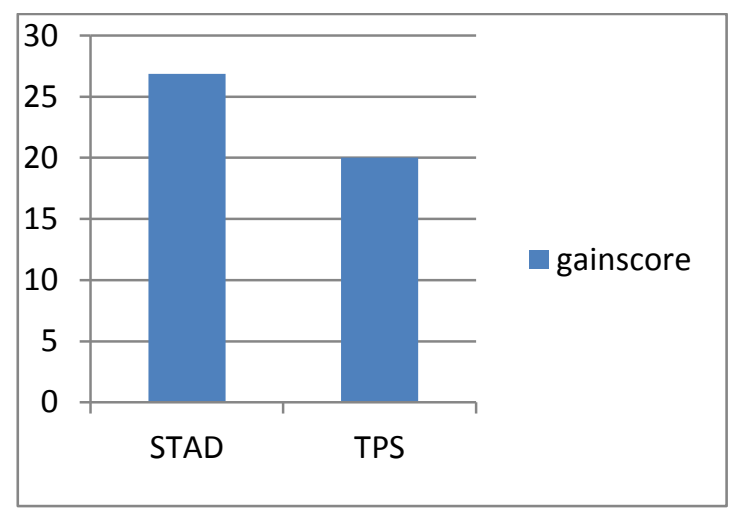

Gambar 2. Perbandingan Gainscore Aktivitas Belajar Siswa Kelompok STAD dan TPS

Uji Normalitas

Hasil perhitungan statistik uji normalitas dapat dilihat pada Tabel 8.

Tabel 8. Hasil Uji Normalitas

\begin{tabular}{llllll}
\hline Aspek & Metode & Statistic & df & Sig. & keterangan \\
\hline Kerja sama & STAD & .109 & 32 & .200 & Normal \\
Siswa & TPS & .140 & 32 & .116 & Normal \\
Aktivitas & STAD & .132 & 32 & .165 & Normal \\
Belajar Siswa & TPS & .110 & 32 & .200 & Normal \\
\hline \multicolumn{2}{l}{ Sumber: Olah data 2016 }
\end{tabular}

Dari hasil uji normalitas pada Tabel 8 dapat dilihat bahwa kelompok kelas eksperimen 1 dengan penerapan metode STAD berasal dari kelompok yang berdistribusi normal. Hal ini dapat dilihat dari hasil signifikansi Kolmogorov-Smirnov pada aspek kerja sama siswa menunjukkan bahwa signifikansi $0,200>0,05$ dan aspek aktivitas belajar siswa menunjukkan signifikansi $0,165>0,05$ yang berarti data berasal dari populasi yang berdistribusi normal. Sedangkan kelas eksperimen 2 dengan penerapan metode TPS juga berasal 
dari kelompok yang berdistribusi normal. Hal ini dapat dilihat dari hasil signifikansi $\mathrm{Kol}$ mogorov-Smirnov pada aspek kerja sama siswa menunjukkan bahwa signifikansi 0,116 > 0,05 dan aspek aktivitas belajar siswa menunjukkan signifikansi $0,200>0,05$ yang berarti data berasal dari populasi yang berdistribusi normal.

\section{Uji Homogenitas}

Hasil perhitungan statistik uji homogenitas dapat dilihat pada Tabel 9.

Tabel 9. Hasil Uji Homogenitas

\begin{tabular}{llllll}
\hline Aspek & $\begin{array}{l}\text { Levene } \\
\text { Statistic }\end{array}$ & df1 & df2 & Sig. & Keterangan \\
\hline $\begin{array}{l}\text { Kerja sama } \\
\text { Siswa }\end{array}$ & .261 & 1 & 62 & .611 & Homogen \\
$\begin{array}{l}\text { Aktivitas } \\
\text { Belajar Siswa }\end{array}$ & .392 & 1 & 62 & .533 & Homogen \\
\hline $\begin{array}{l}\text { Sumber: Olah data } 2016 \\
\text { Sumber }\end{array}$ & & & &
\end{tabular}

Berdasarkan Tabel 9, dapat dilihat bahwa aspek kerja sama siswa menunjukkan signifikansi 0,611>0,05 sedangkan aspek aktivitas belajar siswa menunjukkan signifikansi $0,533>0,05$ sehingga dapat disimpulkan bahwa terdapat kesamaan varian antara kelas yang diuji. Hasil tersebut membuktikan bahwa asumsi homogenitas telah dipenuhi, dengan demikian proses analisis dapat dilanjutkan pada uji hipotesis penelitian.

\section{Uji Hipotesis}

Berdasarkan uji prasyarat analisis, telah menunjukkan bahwa data terdistribusi normal dan homogen, maka pengujian hipotesis dapat dilakukan. Pengujian hipotesis dilakukan dengan menggunakan Independent Sample $T$ Test. Hipotesis penelitian diuji pada taraf signifikansi 0,05 atau 5\%, dengan kata lain menggunakan taraf kepercayaan 95\%. Kriteria pengujiannya apabila nilai signifikasi $<0.05$ maka $\mathrm{H}_{0}$ ditolak dan apabila nilai signifikasi $>0.05$ maka $\mathrm{H}_{0}$ diterima.

Setelah dilakukan analisis dengan menggunakan uji-t didapatkan hasil sebagaimana disajikan pada Tabel 10. Berdasarkan hasil uji-t pada Tabel 10, kerja sama siswa menunjukkan signifikansi sebesar $0,013<0,05$ yang artinya hipotesis nol $\left(\mathrm{H}_{0}\right)$ pertama ditolak, dengan demikian dapat disimpulkan bahwa terdapat perbedaan peningkatan kerja sama siswa yang signifikan antara kelas yang menggunakan metode Student Team Achievement Division dan metode Think Pair Share dalam pembelajaran IPS di kelas VII SMP Negeri 1 Margoyoso Pati Jawa Tengah sedangkan untuk aktivitas belajar siswa menunjukkan signifikansi sebesar $0,011<0,05$ yang artinya hipotesis nol $\left(\mathrm{H}_{0}\right)$ kedua ditolak, dengan demikian dapat disimpulkan bahwa terdapat perbedaan peningkatan aktivitas belajar siswa yang signifikan antara kelas yang menggunakan metode Student Team Achievement Division dan metode Think Pair Share dalam pembelajaran IPS di kelas VII SMP Negeri 1 Margoyoso Pati Jawa Tengah.

Tabel 10. Uji-t

\begin{tabular}{llllll}
\hline & $\begin{array}{l}\text { Levene } \\
\text { Statistic }\end{array}$ & $\mathrm{t}$ & Df & Sig. & Kesimpulan \\
\hline $\begin{array}{l}\text { Kerja sama } \\
\text { siswa }\end{array}$ & .611 & 2.543 & 62 & .013 & $\begin{array}{l}\text { Terdapat } \\
\text { perbedaan } \\
\text { Aktivitas } \\
\text { belajar siswa }\end{array}$ \\
\hline 533 & 2.631 & 62 & .011 & $\begin{array}{l}\text { Terdapat } \\
\text { perbedaan }\end{array}$ \\
\hline
\end{tabular}

Sumber: Olah data 2016

\section{Simpulan}

Berdasarkan uraian, hasil penelitian dan pembahasan yang telah dipaparkan, maka dapat disampaikan simpulan penelitian sebagai berikut. Pertama, terdapat perbedaan peningkatan kerja sama siswa yang signifikan antara kelas yang menggunakan metode Student Team Achievement Division dan metode Think Pair Share dalam pembelajaran IPS di kelas VII SMP Negeri 1 Margoyoso Pati Jawa Tengah. Hal ini dibuktikan dengan hasil uji $t$ dengan taraf signifikansi 0,05 menunjukkan $0,013<0,05$ sehingga $H_{o}$ ditolak dan hasil analisis data angket kerja sama siswa dengan penerapan metode Student Team Achievement Division memiliki nilai rata-rata gainscore sebesar 29,69 dan metode Think Pair Share sebesar 24,69, yang artinya metode Student Team Achievement Division dapat meningkatkan kerja sama siswa lebih tinggi dibandingkan metode Think Pair Share.

Kedua, terdapat perbedaan peningkatan aktivitas belajar yang signifikan antara kelas yang menggunakan metode Student Team Achievement Division dan metode Think Pair Share dalam pembelajaran IPS di kelas VII SMP Negeri 1 Margoyoso Pati Jawa Tengah. Hal ini dibuktikan dengan hasil uji t dengan 
taraf signifikansi 0,05 menunjukkan 0,011 < 0,05 sehingga $\mathrm{H}_{0}$ ditolak dan hasil analisis data angket aktivitas belajar siswa dengan penerapan metode Student Team Achievement Division memiliki nilai rata-rata gainscore sebesar 26,88 dan metode Think Pair Share sebesar 20,84, yang artinya metode Student Team Achievement Division dapat meningkatkan aktivitas belajar lebih tinggi dibandingkan metode Think Pair Share.

Berdasarkan simpulan penelitian tersebut, maka saran yang dapat disampaikan pada penelitian ini adalah sebagai berikut. Pertama, dalam melaksanakan pembelajaran di kelas guru hendaknya menerapkan metode STAD dan TPS pada materi usaha manusia untuk mengenali perkembangan lingkungannya dan materi perkembangan masyarakat sejak masa hindu budha sampai kolonial eropa karena terbukti dapat meningkatkan kerja sama dan aktivitas belajar siswa.

Kedua, untuk mengoptimalkan aspek kerja sama dan aktivitas belajar siswa dalam pembelajaran IPS, guru hendaknya menerapkan metode pembelajaran STAD dan TPS pada kondisi siswa yang kondusif atau diterapkan pada pagi hari agar lebih maksimal. Apabila guru menggunakan metode tersebut pada siang hari lebih baik dikombinasikan dengan metode pembelajaran yang bersifat permainan dan media pembelajaran yang menarik sehingga siswa akan lebih bersemangat dalam mengikuti pembelajaran.

\section{Daftar Pustaka}

Arifin, Z. (2011). Penelitian pendidikan metode dan paradigma baru. Bandung: PT. Remaja Rosdakarya.
Harsanto, R. (2007). Pengelolaan kelas yang dinamis: Paradigma baru pembelajaran menuju kompetensi siswa (5th ed.). Yogyakarta: Kanisius.

Huda, M. (2011). Cooperative learning: Metode, teknik, struktur dan model terapan. Yogyakarta: Pustaka Pelajar.

Lie, A. (2004). Cooperative learning: Mempraktikkan cooperative learning di ruang-ruang kelas. Jakarta: PT. Grasindo.

Republik Indonesia. peraturan pemerintah republik Indonesia nomor 32 tahun 2013 tentang perubahan atas peraturan pemerintah nomor 19 tahun 2005 tentang standar nasional pendidikan (2013).

Sapriya. (2011). Pendidikan IPS. Bandung: PT Remaja Rosdakarya.

Sardiman. (2010). Interaksi dan motivasi belajar mengajar. Jakarta: Rajawali Press.

Solihatin, E., \& Raharjo. (2012). Cooperative learning: Analisis model pembelajaran IPS. Jakarta: PT.Bumi Aksara.

Supardi. (2011). Dasar-dasar ilmu sosial. Yogyakarta: Penerbit Ombak.

Sutanto, A. (2015). Teori belajar \& pembelajaran di sekolah dasar. Jakarta: Prenadamedia Group.

Zubaedi. (2011). Desain pendidikan karakter konsepsi dan aplikasinya dalam lembaga pendidikan. Jakarta: Kencana Prenada Media Grup. 